\title{
ALTERNATIVE VIEWS ON DEVELOPMENT FOR THE COASTAL PLAINS REGION
}

\author{
Emil Malizia and Charles Richter*
}

University of North Carolina

The problems of less developed regions have provided an important area of study for regional scientists and planners during the past decade. Theoretical and applied work, while not without diffe rences and disag reements, constitutes a particular conception of the development process drawn from neo-classical economics. This research has influenced the goals, analyses, programs and projects of the Appalachian Regional Commission and the Regional Commissions of the Economics Development Administration. ${ }^{1} \mathrm{~A}$ detailed evaluation of these efforts is beyond the scope of this paper. Instead, we present an alternative concept of development and an alternative set of strategies for stimulating regional development. Both the conception and the strategies which follow from it diverge from traditional analyses and strategies sanctioned by government sponsorship. We use the Coastal Plains Region and its regional development plan to bring out the differences between our viewpoint and the traditional view.

\section{THE CONCEPT OF DEVELOPMENT}

The familiar conventional approach to understanding the problem of lagging regions involves applications of economic analysis through trade theory, location theory and development theory. This approach usually explains the problems of lagging regions in terms of comparative disadvantages and disequilibrium conditions primarily in factor markets. ${ }^{3}$ We take a different point of departure whichemphasizes inherent tendencies in the political economy toward uneven development. These tendencies are best understood through an historical analysis of economic and political structures, social institutions and stratification, and their interrelationships. To elaborate briefly we distinguish among undeveloped, underdeveloped and developed regions.

Drawing from the economic history of the United States, one can study the processes by which an undeveloped area, rich in natural endowments and free of feudal institutions, has grown into an affluent nation. Development was initiated, stimulated and increased by enlarging the amount of economic surplus and transforming that surplus into productive capital stock. 4 Undeveloped regions were penetrated and subquently integrated through specialization into the political economy as industrialization and urbanization proceeded. Institutional forces were important. Legal structures fostered the consolidation of land and natural resources under private ownership and the creation of labor markets which mobilized the labor power of wage-earners and slaves. The state actively promoted development with favorable regulation and with public investments particularly in transportation networks. Private investment and capital accumulation thrived in this favorable institutional and natural environment. Technological advancement created a complementary dynamic for capital intensification, mass production, mass consumption and territorial expansion. In brief, tendencies of capitalist development revolutionized the economic base and superstructure of undeveloped regions. The division of labor, productive wealth, commodity production and per capita income increased with the ebb and flow of business cycles.

* The authors aregrateful to George Iden and Francis Parker for their comments on a preliminary draft of this manuscript. 
Yet temporal fluctuation failed to exhaust the uneven nature of the development process. Social inequality reflected in the distributions of income, wealth and political power among families and individuals increased as well. Only a small number of people came to own significant amounts of land, capital or financial assets. The distribution of income in this country has not shown much change since World War $\mathrm{II}^{5}$ the distribution of wealth appears to manifest increasing inequality. 6 Finally, the process generated an uneven spatial distribution of development. Favored locations became the nodes of industrialization. Some grew into metropolitan centers of financial and economic power.

Other areas fell behind receiving relatively less new investment, less useful and lower per capita incomes. The keyquestion is why are these regions less developed. Obviously, some fall victim to detrimental changes in technology or tests or to natural resources depletion and lose considerable population and economic activity. In extreme cases, areas revert to a state of undevelopment. But a more important group of regions, while maintaining significant amounts of population and economic activity, become permanently underdeveloped. Putting aside the numerous ghetto areas within metropolitan communities, the Coastal Plains, the Mississippi Delta and Central Appalachia serve as examples of multi-county, underdeveloped regions.

The reason is two-fold. The tendency for social inequality engenders dominant-subordinant relationships between the few and the many. In simplest terms, concentrated wealth breeds concentrated power which eventually generates effective controlover the political economy. Social norms support the status quo by providing rationalizations for inequality. The subordination of large numbers of people is a function of class and race. In the Coastal Plains and Delta regions, a small landowning, banking and commercial minority guides the local economy and thereby continues to appropriate much of the economic surplus available to regional residents. These areas are underdeveloped regions, underdeveloped due to internal structures and relations hips which perpetuate the subordination of the masses. 7

The other part of the answer is that these areas enter into subordinate relationships to more developed regions largely due to unfavorable terms of trade, relatively high rates of profit and exploitation, much absentee ownership or control and inadequate national political power. The dominance of developed regions is reflected in their ability to drain economic surplus from subordinate regions and to utilize the surplus which remains so as to abrogate the development potential of subordinate areas. 8 In this sense also, subordinate regions are underdeveloped regions, underdeveloped due to external relationships which perpetuate the subordination of the masses.

Many studies document the net outflow of economic surplus from underdeveloped countries to metropolitan centers. 9 Others report on higher rates of economic growth that resulted from closing off underdeveloped regions to continued foreign exploitation. 10 Still another traces the realization of development back to the absence of previously detrimental external relationships. 11 Central Appalachia provides the best example of an underdeveloped region in the U.S. in terms of drain of surplus from its natural resources and labor power for development elsewhere. To forcefully summarize the point, developed regions are often parasitic upon underdeveloped regions.

From this cursory analysis, we would argue that the central problem of an underdeveloped region, a persistently low level of relative human welfare, is caused by unequal relationships to a local elite or to developed regions. Thus, our target population includes working class and underclass people alone. As well as having low levels of material welfa re, these people 
exert little control over their work and over political-economic decisions that influence their lives. The relevant goal for regional development planning is to increase both material and non-material welfare of workers and poor persons in underdeveloped areas.

\section{DEVELOPMENT STRATEGIES FOR THE COASTAL PLAINS REGION}

Having presented a framework to view underdevelopment, we now focus our attention on one underdeveloped region in the United States, the Coastal Plains Region. The Coastal Plains includes about one-half the area in the eastern portions of North Carolina, South Carolina, and Georgia. Per capita income in this region averaged $\$ 1993$ in 1967 compared to \$3159 in the nation. Income is distributed quite unequally among the population of this area ${ }^{12}$ which suggests that there exists an affluent class in the region. 'Foreign' corporate control over the region is limited to forestry and only a few agricultural sectors. Thus, this local class forms the core of the regional power structure.

A plan for development of the Coastal Plains focuses on the gap between per capita income of the region and that of the nation. ${ }^{13}$ The plan offers suggestions for closing this gap by 1980. While closing the income gap may benefit some of the region's people, it fails to deal with social inequality and implicitly assumes a high correlation between levels of per capita income and material welfare.

The report of the Coastal Plains Commission describes the attributes of an underdeveloped region without explaining the causes of underdevelopment. Failure to grasp the forces generating underdevelopment results in a strategy of restructuring the region's industrial mix to achieve the stated goal. The methods of input-output analysis and linear programming are utilized to exemplify a path of industrialization for making the Coastal Plains conform to the economic structure of more developed areas. Yet the structures of ownership, control, power and privilege are ignored.

Similarly a study by Vincent Tarascio recommends a program of industrialization for the Coastal Plains not only because it will increase per capita incomes of the region's residents, but because industrialization will even the distribution of incomes within the regions. 14 Tarascio reached this conclusion after noticing that the Piedmont section of the Carolinas and Georgia has both a higher level of per capita income and a more equal distribution of income than the Coastal Plains and Mountain parts of the states. He attributed the more developed position of the Piedmont to the higher degree of industrialization in the area.

While it may be correct that industrialization can raise per capita incomes, industrialization may not be advantageous to poor persons in the region. It may raise per capita incomes by bringing new persons into the region without benefitting the persons already living there. The impact industralization would have on income distribution in the Coastal Plains is not clear. Literature in development economics has not yielded conclusive evidence whether industrialization does or does not tend to even the distribution of incomes. In Mexico studies have shown that incomes have become more unevenly distributed with industrialization. 15

The underlying logic of the development strategies for the Coastal Plains is that public investments to develop human resources, access, infrastructure and growth poles accompanied by public subsidies to businesses will stimulate additional private investments which, in turn, will make more lucrative jobs available in the region. The logic would be most sensible if we were discussing approaches to the development of the American fron- 
tier about 100 years ago. The approach exemplifies the precedents established by traditional government policies designed to foster capitalist exploitation of undeveloped regions. But, as we have tried to argue, underdevelopment is a process resulting from internal andexternal structures and relationships. To overcome underdevelopment, we must change more than the functional specialization of the Coastal Plains economy. We must modify institutional and power structures in the political economy. We must alter the amount and modes of economic surplus utilization in favor of poor and working people. Only then will our programs reach the majority of Coastal Plains residents in a manner which will improve their well-being.

It is possible to outline a continuum of development strategies for improving the welfare of workers and poor people in underdeveloped regions. At one extreme, basic institutions would be changed, particularly modes of production and appropriation which determine the amount and utilization of economic surplus. At the other extreme, existing structures would be slightly modified. All the strategies are feasible in a technological sense. However, some may appear utopian if the existing distribution of political power is viewed as an unalte rable constraint.

One strategy would involve the establishment of self-governing bodies democratically controlled from below that would plan, implement and defend development programs. These bodies would control, through their constituents all natural resources and capital stock. Productive wealth, as opposed to residential property and consumer durables, would be expropriated by the local bodies for their utilization. These bodies would autonomously make production and distribution decisions and participate in more inclusive federations to realize necessary coordination.

Another strategy would establish worker control overindustrial production by turning over plant and equipment to local workers. ${ }^{16}$ An important ingredient for the success of these decentralized strategies would be an effective information system to promote informed decisions in the absence of either extreme centralization or the market mechanism. It is likely that the above two strategies would notoccur outside the context of revolutionary change. Are there other alternatives?

All levels of government would take a more active role in promoting taxation, expenditure and regulatory policies which could benefit the majority of persons. Taxes could be made more progressive. Regulatory powers could be used to control.big finance and business in order that corporations will act more in the interests of consumers and citizens. Yet to suggest changes in the behavior of government is to assume considerable alternation in the interests represented by public officials and bureaucrats.

A more moderate strategy would focus on the non-agricultural labor force, especially in manufacturing sectors. Here a unionization strategy would be supported to increase wage rates and improve working conditions. This strategy would foster short run gains and erode the region's major 'advantage' -- cheap labor. But more importantly, this strategy is one way to organize the people. Virtually any social service programcentered in rural non-farm or urban communities could provide the impetus to people's organizations. Organizing frombelow for change is a potent process for overcoming undevelopment.

In summary, our strategies would be characterized as redistribution for development. They focus on the redistribution of political power, economic wealth in the form of natural resources and productive capital, income and social services in that order of importance. The strategies implyour 
pessimism about the likelihood that local or national elites will decide to carry out meaningful redistributive policies and our assumption that meaningful regional development will be initiated through the actions of subordinant groups. 17 Comparable strategies for rural areas in the Coastal Plains are presented in the next section.

\section{RURAL DEVELOPMENT OF THE COASTAL PLAINS REGION}

Despite the exodus of persons from rural areas of the Coastal Plains in the 1950's and early 1960's, there remains a large number of poor persons on farms. In 1967, 11.0 per cent of the region's laborforce was engaged in agriculture compared to 4.9 per cent in the nation. 18 Rural poverty in the region is directly related to low earnings from agriculture. In 1965, average earnings of full-time agricultural employees in the Coastal Plains was $\$ 1,198.19$. This figure is only 58 per cent of the average earnings of full-time agricultural employees in the nation. Thus, there is considerable poverty in agriculture.

It might be as sumed that one factor causing rural poverty is overspecialization in the cash crops of cotton and tobacco. Contrary to conventional beliefs, the Coastal Plains has a relatively diverse mix of crops. Table 1 shows the percentage of harvested acreage devoted to the production of five specific crops and truck farms. Although tobacco is a more important source of income than the other crops, tobacco and cotton covered only 21.5 per cent of crop land. The soil characteristics in the Coastal Plains can adequately support a diversified crop mixture.

Table 1. Per Cent of Harvested Cropland Devoted to Specific Crops 1964

Coastal Plains $\quad \underline{\text { N.C. }} \quad \underline{\text { S.C. }}$

Corn (used for grain)

Cotton

Peanuts

Soybeans

Tobacco

Truck farming

$$
\begin{array}{r}
34.1 \\
15.9 \\
8.5 \\
17.1 \\
5.6 \\
4.4 \\
\hline 85.6
\end{array}
$$

\begin{tabular}{|c|c|}
\hline S.C. & Ga. \\
\hline 23.0 & 45.9 \\
\hline 24.2 & 14.5 \\
\hline .6 & 14.5 \\
\hline 33.1 & 4.3 \\
\hline 3.9 & 2.0 \\
\hline$\frac{3.9}{88.5}$ & $\frac{6.9}{88.1}$ \\
\hline
\end{tabular}

Source: Charles F. Floyd, "Economic Profile of the Coastal Plains Region," College of Business Administration, University of Georgia (January 1970), pp. $150-170$.

A more viable explanation of why so many farmers are poor in the South is related to the small sizes of individual farms. The agricultural profile in the Coastal Plains given in Table 2 shows that farms are smaller in the region than in the nation. Although it is difficult to demonstrate conclusively that small farms fail to realize economies of scale, we suspect that it would be more efficient if farmers utilized larger plots of land. But regardless of efficiency considerations, small farms indicate high risk, under capitalization, lower skill level, and higher costs, factors correlated with marginal agriculture. 
Table 2. Percentages of Farms in Given Size Classes 1964

$\underline{\text { Coastal Plains } \quad \text { U.S. }}$

1 - 9 acres 20.5

10 - 19 acres 20.4

20 - 29 acres 15.3

30 - 49 acres 16.9

14.8

7.3

$100-199$ acres

3.8

18.1

$200-499$ acres

.8

12.7

8.6

11.5

17.1

16.8

500 - 999 acres

1,000 or more acres

Source: Compiled from the Census of Agriculture, 1964.

A related and, to us, more important cause of rural poverty is the land tenure system. While 17.1 per cent of U.S. farms in 1964 were operated by tenants, 41.0 per cent of farms in the Coastal Plains were operated by tenants, more than twice the percentage of tenancy arrangements in the nation. 20 The large majority of tenants are Black. The existing tenure conditions are more closely linked to the institution of slavery than to the institution of agrarian democracy.

Several possibilities exist to alleviate rural poverty. One is to encourage marginal farmers to leave the land. The exodus from farms has been substantial to date. Unfortunately, many of these persons face tight labor markets in urban areas and lackaccess to skills or union membership often essential for absorption into the labor forces of U.S. cities. Another possibility is to make substantial direct transfer payments available to the poor in the Coastal Plains. It is possible that more people would remain in the region if their material circumstances were improved by public support Yet this approach does not attack the production relationships which perpetuate subordination. Another alternative would involve programs to improve conditions on the farms. 21 While we do not necessarily reject the former alternatives, we are especially interested in exploring ways to improve rural conditions. Governmental efforts to discuss the problem of rural poverty have exceeded the generation of viable programs to help poor farmers in the South. 22

We suggest that two specific strategies be considered for improving rural conditions in the Coastal Plains Region--land reform and cooperative agricultural development.

Although it has been common for North American economists to suggest agrarian reforms in Latin American, ${ }^{23}$ they have not suggested a land reform program in the United States. Notwithstanding the differences between land tenure situations in the Third World and the U.S., substantial similarities warrant investigation of a land reform in the Coastal Plains. In essence, land reform could be accomplished by government purchasing land from present owners, particularly wealthy and absentee landlords, and redistributing this land to the poorer persons engaged in agriculture. 
There are two specific possibilities. First, tenancy could be eliminated by using government grants or loans to transfer titles to poor farmers. The benefits would be three-fold. The farm earnings of poor farmers would increase if they could keep the entire value of the product of their labor, rather than having to turn over part of this value in the form of rent or other payments to landlords. In addition, poor farmers would gain a minimal amount of equity through land ownership. Thus, their wealth position would improve regardless of whether they chose to remain in or leave farming. Finally, the political dependency fostered by tenancy would begin to decrease with greater economic freedom and security of the poor farmer. Second, government intervention could eliminate tenancy by reorganizing landholdings available to poor farmers. A plan for reorganization could be developed that expanded the scale of operation of poor farmers and linkedtechnical assistance and other programs to the reform program.

It may be possible to use the power of eminent domain to implement land reform in the U.S. Eminent domain power, traditionally limited to public use, has beenused in urban renewal for the public purposes of slum clearance. The power could be applied to a land reform if the elimination of rural poverty is deemed as a public purpose by the courts.

A variant strategy would redistribute various forms of agricultural support in lieu of or in addition to land. The program would strive to increase the income net-worth position of poor farmers. Although this objective could be articulated in several ways, reallocation of tobacco allotments would have the greatest impact on the earnings of poor farmers in the Coastal Plains. Allotments could be reassigned until acreage and poundage limits were reached. This program would eliminate allotment leasing, erode capital gains which have become capitalized into land values but not necessarily alter the existing pattern of many small allotment holdings. 24

Another strategy to improve rural conditions would involve assistance to poor people's cooperatives. For many years these types of cooperatives have existed in the South ${ }^{25}$ and in many Third Worldnations. 26 Poor people's cooperatives in both the U.S. and other nations have had a mixed record of successes and failures. Cooperatives functioning in the areas of production, distribution and credit appear most attractive for the region.

Cooperatives offer many advantages in attacking rural poverty. They can increase the poor farmer's surplus by lowering the costs of raw material and distribution. They have been used by American farmers to bypass middlemen in purchasing machinery and supplies. Cooperatives have also enabled farmers to sell their products at more favorable prices and with milder price fluctuations than exist in the open market. Many rural cooperatives have given farmers access to credit which could not be obtained from private banks and other lending institutions. In other words, the services provided by cooperatives are for the benefit of the cooperative's members, rather than for private gains. Thus, whatever surplus a cooperative may gain is turned over to its members in the form of technicalassistance, cash payments, or both.

Other advantages are related to potential linkages between rural producer cooperatives and community development efforts. In both cases the constituency is predominantly Black, and tradeagreements could be mutually advantageous tying together production in the rural area, transportation to urban areas and retail distribution in community controlledestablishments. Complementary activities like food processing could add to the employment and earning potential of the cooperative endeavor. 
But whatever economic advantages may exist, one of the main advantages is socio-political. Cooperatives afford to poor people the opportunity to gain control over the institutions that formerly oppressed them. It has been argued elsewhere that the most likely way to alleviate rural poverty is for the poor to exert control over organizations and to strive for changes through them. 27 We would concur.

The major problems faced by poor people's cooperatives are that they are often short of capital, that they create heavy demands for effective coordination, and that they usually suffer from poor management. These difficulties are related to the central problem--strong competition from la rger producers and processors in the region and outside of it. Competition puts emphasis on high quality, uniform produce that can be marketed or processed at the correct point in time in order to meet consumer demand or to maintain full capacity utilization of processing plant and equipment. 28

The choice in planning tor effective cooperative development seems clear. Either the cooperative must operate much like a big farm businessor it must produce rather non-competitive commodities for which an adequate market exists. The former alternative involves direct competition for mass agricultural markets or securing government contracts for sale of agricultural commodities. The latter requires producing commodities like ornamentals, organic foods, gourmet products, hand-made furniture and accessories, etc.

Although poor people's cooperatives remain marginal, they are still quite numerous in the South and have demonstrated their viability by surviving without ample funds or managerial ability. At the present time some southern cooperatives have received assistance from the OEO and from the Department of Agriculture. The amount of assistance has been small and appears smaller yet when compared to more expensive farm programs which benefit primarily wealthy farmers. Most of the policies adopted by the Department of Agriculture have benefitted large-scale farmers by apportioning aid on the basis of farm size or establishing price supports which yield greater gains to large farmers. These policies have subsidized capital at the expense of smaller producers who have not been strong enough to obtain requisite capital stock for efficient levels of production. 29

We recommend that the federal government consider increased funding for poor people's cooperatives, for land reform and for other programs to help the rural poor improve their positions in the Coastal Plains or to assist those who wish to migrate out of rural areas. We further suggest that funding be provided without placing additional burdens on taxpayers. Specifically, the Department of Agriculture should shift its resources from large producers to aid small and poor farmers. We see no sound reason for the federal government continuing its support of wealthy farmers and corporations to protect them from overproduction.

Hopefully, we have raised some important questions for those interested in regional development. The causes of underdevelopment can be explained by using a broader set of variables, particularly structural attributes of the political economy, and by taking an historical perspective on existing problems. The discussion of development strategies can be extended to include strategies which have some potential for altering the internal and external conditons that sustain underdevelopment in the United States. 
${ }^{1}$ For example, see Southern Regional Education Board, A Review of Regional Economic Research and Planning on the Coastal Plains Region/Washington: Office of Development Administration, Economic Development Administration, U.S. Dept. of Commerce, 1967): Economic Development Administration, Progress Reports (Washington: U.S. Dept. of Commerce, 19661971); Appalachian Regional Commission, Developing a Strategy for Growth (Washington: Appalachian Regional Commission, October 1966); and Donald N. Rothblatt, Regional Planning: The Appalachian Experiment (Lexington: Heath Lexington Books, 1971).

${ }^{2}$ Coastal Plains Regional Commission, Economic Development Plan (August, 1971).

${ }^{3}$ For example, see George H. Borts and Jerome L. Stein, Economic Growth in a Free Market (New York: Columbia University Press, 1964); John Friedmann and William Alonso, eds. , Regional Development and Planning (Cambridge: M.I. T. Press, 1964), Part 3; and Niles M. Hansen, Rural Poverty and the Urban Crisis (Bloomington: Indiana University Press, 1970). Ch. 1 .

${ }^{4}$ For our purposes, the economic surplus can be defined as the difference between production and consumption. Further discussion is in Paul A. Baran, The Political Economy of Growth (New York: Monthly Review Press, 1957), especially Ch. 2 .

${ }^{5}$ Frank Acherman, et. al. , "Income Distribution in the United States," The Review of Radical Political Economics, (Summer 1971), pp. 20-43.

${ }^{6}$ David M. Gordon, Problems in Political Economy: An Urban Perspecitive (Lexington: D. C. Heath and Company, 1971), p. 244.

${ }^{7}$ Many studies have discussed the internal structure of underdeveloped countries in terms of the domination-subordination thesis. Recent examples include Thomas E. Weisskopf, "Capitalism, Underdevelopment and the Future of Poor Countries, "and Michael Meeropol, "Toward a Political Economy Analysis of Underdevelopment, "The Review of Radical Political Economics, (Winter 1972), pp. $1-35$ and pp 77-108, respectively; and Paulo Freire, Pedagogy of the Oppressed (New York: Herder and Herder, 1971).

${ }^{8}$ The surplus drain thesis has been criticized for not taking an empirical, opportunity cost approach to the question. (See Charles Nisbet, "Transferring Wealth from Underdeveloped to Developed Countries Via Direct Foreign Investment, "Southern Economic Journal, (July 1970), pp. 93-96. Neither does the conventional argument about the mutually beneficial effects of foreign trade. The question is an empirical one for all concerned. We would argue that the appropriation of economic surplus by a local elite or by foreign capital and its utilization in their interests is to be expected instead of looking to the past to find an opportunity set, a more valid opportunity cost approach would look to the future: Compare existing modes of surplus appropriation and utilization to alternative opportunities under more rational, people-focused political and economic institutions.

${ }^{9}$ For example, Andre G. Frank, Capitalism and Underdevelopment in Latin America (New York: Monthly Review Press, 1967); and T. Dos Santos, "The Structure of Dependence," American Economic Review, (May 1970), 
pp. $231-236$.

${ }^{10}$ See H. J. Bruton, "Productivity Growth in Latin America," American Economic Review, (December 1967), pp. 1099-1116; and Branko Horvat, "Comment," in J.H. Adler, ed., Capital Movements and Economic Development (New York: St. Martin's Press, 1967), pp. 229-236.

${ }^{11}$ Baran, op. cit., pp $158-162$ and 186-187.

12 Over half the Gini coefficients for the Coastal Plains were found to exceed . 45 in a study examining income distribution in the Carolinas and Georgia using 1960 data. In the remainder of these states, about 12 per cent of the county Gini coefficients exceeded .45. High Gini coefficients are indicative of unequal distributions of income. Gini coefficients for counties in the Carolina, and Georgia can be found in Vincent J. Tarascio, "Fiscal Aspects of Human Resource Development, "Research Paper Number 19, (Chapel Hill: School of Business Administration, University of North Carolina, January, 1971), p. 8.

${ }^{13}$ Coastal Plains Regional Commission, op. cit.

14 Tarascio, op. cit., pp. 3-13.

${ }^{15}$ The results of these studies a re summa rized in Leopoldo Solis, "Mexican Economic Policy in the Post-War Period: The Views of Mexican Economists," American Economic Review, supplement, (June 1971), pp. 25-28.

16 For elaboration, see Andre Gorz, Strategy for Labor (Boston: Beacon Press, 1969), and Jaroslav Vanek, The General Theory of Labor-Managed Market Economies (New York: Cornell University Press, 1970)

${ }^{17}$ For a fuller elaboration on growth strategies focusing on the poorest persons see John W. Gurley, "Maoist Economic Development: The New Man in the New China," The Review of Radical Political Economics, (Fall 1970), pp. $26-38$.

${ }^{18}$ Charles F. Floyd, (Economic Profile of the Coastal Plains) Region, College. of Business Administration, University of Georgia (January, 1970), p. 70 .

19 Charles F. Floyd, "The Changing Structure of Employment and Income in the Coastal Plains Development Region, "University of Georgia (March, 1969), p. 118. p. 142 .

20Floyd, "Economic Profile of the Coastal Plains Region," op. cit.,

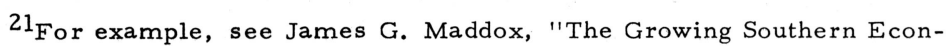
omy, "in Southern Regional Education Board, The Future South and Higher Education (Atlanta: SREB, 1968), pp. 35-68; and William H. Nicholls, "The U.S. South as an Under-Developed Region," in U. Papi and C. Nunn, eds., Economic Problems of Agriculture in Industrial Societies (New York: St. Martin's Press, 1969), pp. 469-493.

${ }^{22}$ See Sidney Baldwin, Poverty and Politics (Chapel Hill: University of North Carolina Press, 1968): Donald H. Grubbs, Cry From Cotton (Chapel Hill: University of North Carolina Press, 1971); and James G. Maddox, "An Historical Review of the Nation's Efforts to Cope with Rural Poverty, "American Journal of Agricultural Economics, (December 1968), pp. 1351-1361. 
23 For instance, see Harvey S. Perloff, Alliance for Progress (Baltimore: The Johns Hopkins Press, 1969), p. 125 or John P. Powelson, Latin America: Today's Economic and Social Revolution (New York: McGraw Hill, 1964), p. 68 .

${ }^{24}$ Discussion with Dale Hoover, March 7, 1972. See also Dan Parrlberg, American Farm Policy (New York: John Wiley \& Sons, Inc. , 1964), pp. 226 236.

${ }^{25}$ See Ray Marshall and Lamond Godwin, Cooperatives and Rural Poverty in the South (Baltimore: The Johns Hopkins Press, 1971).

${ }^{26}$ Advisory Commissionon Overseas Cooperative Development,"Farmer Cooperatives in Developing Countries," (October 1971).

${ }^{27}$ Marshall and Godwin, op. cit., p. 3.

28 Interview with James G. Maddox, Raleigh, North Carolina, February 15,1972 . 134-135.

${ }^{29}$ Marshall and Godwin, op. it., p. 25; and Paarlberg, op cit, p. 